\title{
Effect of phytase in laying hen diets with different phosphorus sources
}

- Author(s)
Casartelli $\mathrm{EM}^{1 *}$
Junqueira $\mathrm{OM}^{1}$
Laurentiz $\mathrm{AC}^{1}$
Filardi RS'
Lucas Júnior $\mathrm{J}^{2}$
Araujo LF
1 Departamento de Zootecnia, FCAV,
Universidade Estadual Paulista, Jaboticabal.
Via Prof. Paulo Donato Castellane, S/n,
Jaboticabal, São Paulo, Brasil.
2 Departamento de Engenharia Rural, FCAV,
Universidade Estadual Paulista, Jaboticabal.
Via Prof. Paulo Donato Castellane, S/n,
Jaboticabal, São Paulo, Brasil.
3 Serrana Nutrição Animal S/A

Mail Address

Elenice Maria Casartelli

Avenida Líbero Badaró, 810

Centro

14.870-540. Jaboticabal, SP

E-mail: emcasartelli@yahoo.com.br

\section{- Keywords}

Commercial laying hens, eggshell quality, phosphorus sources, phytase enzyme.

\section{ABSTRACT}

An experiment was conducted to evaluate the effects of the enzyme phytase in diets formulated with different phosphorus sources on performance, eggshell quality and excretion of commercial laying hens. Two hundred and eighty-eight commercial Hyssex Brown laying hens were evaluated during two production phases, which included eight twenty-eight-day cycles, using a completely randomized design in a $3 \times 2$ factorial with six replicates of eight birds per treatment. Three phosphorus sources (calcium and sodium phosphate, micro-granulated dicalcium phosphate and triple super phosphate) and two phytase levels (0 or $1000 \mathrm{FTU} / \mathrm{kg}$ diet) were tested in the composition of the diets. After the post-peak period, triple super phosphate decreased bird performance and eggshell quality. It was possible to reduce the levels of phosphorus supplementation when phytase was added to the diet. Besides, phytase supplementation reduced phosphorus, calcium and nitrogen excretions, but affected mean egg weight at production peak.

\section{INTRODUCTION}

Bird diets are generally formulated based on corn and soybean meal. All vegetal sources have available phosphorus around 33\%, except for rice bran, which has $20 \%$ of available phosphorus (Rostagno et al., 2000). The $66 \%$ of phosphorus unavailability in almost all vegetal ingredients is a consequence of inositol binding, which forms a molecule of phytic acid or inositol hexaphosphate, a reactive anion responsible for the formation of chelates with divalent cations such as calcium, magnesium, manganese, zinc, copper and iron. Since such organic minerals are very important, this reaction has been proposed as a major antinutritional factor that reduces the availability of these minerals in monogastric animals (Cousins, 1999, Yi et al., 1996).

Due to the low content of available phosphorus in plants and the low phytase activity in birds, diets must be supplemented with an inorganic phosphorus source. Nevertheless, similar to phytic phosphorus, a great proportion of inorganic phosphorus is excreted by birds (Fireman \& Fireman, 1998). The use of inorganic phosphorus in diets has many disadvantages, as the increase of nutrition costs and, consequently, production costs. Besides, river, lakes, fens and underground water contamination are environmental problems caused by the higher phosphorus elimination in the excretions. Such problem is even greater especially when bird manure is used as fertilizer, since the amount of phosphorus added to soil exceeds plant requirements.

According to Syers et al. (1973), phosphorus (P) and nitrogen (N) are considered limiting elements for aquatic plant growth, because their excess causes an increase of the eutrophication process and, consequently, reduction of the water quality. In Brazil, Perdomo (1996) 
Casartelli EM, Junqueira OM, Laurentiz AC, Filardi RS, Lucas Júnior J, Araújo LF

reported high indexes of water pollution in some cities in the South of Santa Catarina State, where many large swine and bird farms are located.

Inorganic phosphorus sources are non-renewable, and this may pose problems to the future. Therefore, the efficiency of vegetal phosphorus utilization must be increased to prevent the gradual reduction in the available sources.

Phytase supplementation of laying hen diets improves the utilization of available phosphorus and other minerals chelated to phytic acid (Boling et al., 2000; Jalal \& Scheideler, 2001; Borrmann et al., 2001; Ceylan et al., 2003 and Keshavarz \& Austic, 2004). The quantification of phosphorus excretions has been studied in birds fed diets with reduced levels of phosphorus and supplemented with phytase and some reports show a reduction of approximately $45 \%$ in phosphorus excretion without affecting performance parameters.

The main mineral source of phosphorus is dicalcium phosphate, which is used worldwide in diet supplementation for livestock. In conventional, cornsoybean meal based diets for birds, sources of inorganic phosphorus must be used to fulfill maintenance and production requirements. This kind of supplementation is performed using inorganic phosphates with high biological availability, as monocalcium and dicalcium phosphates, but the costs are high. Some inorganic phosphorus sources are cheaper, such as natural rock or single super phosphate, but they have low biological availability and undesirable results have been reported in animal nutrition assays, probably because of the high fluorine levels present in these sources.

Another limiting factor of phosphorus digestibility in birds is the particle size, because the larger the particle size, the higher is the mineral availability. Therefore, grinding level is an important variable for inorganic phosphorus utilization by animals (Potter, 1988). However, Burnell et al. (1990) noted to the controversial results of studies that assessed the effects of phosphate sources and particle size on solubility and, consequently, on available phosphorus and calcium. These authors also evaluated five different particle sizes $(2.0,1.25,0.5$, 0.18 and $0.05 \mathrm{~mm}$ of mesh screen) and suggested that larger particles were retained longer in the proventricle, partially blocking food passage. Consequently, the mineral supplement would stay longer within the acid environment of the higher digestive tract and could be dissolved faster than if proceeding to the lower digestive tract.
Effect of phytase in laying hen diets with different phosphorus sources

The aim of this study was to evaluate the effect of phytase in laying hen diets with different sources of phosphorus on performance, eggshell quality and excretion quality.

\section{MATERIAL AND METHODS}

A trial was carried out at Experimental Poultry Farm of Faculdade de Ciências Agrárias e Veterinárias, UNESP, Jaboticabal, São Paulo, Brazil. Two hundred and eighty-eight commercial Hyssex Brown laying hens were housed in cages (two per cage) in 36 experimental parcels with eight birds each. The birds were evaluated during eight periods of 28 days and divided into two phases: peak egg production (32 to 48 weeks of age) and post-peak production (48 to 64 weeks of age).

A completely randomized experimental design in a $3 \times 2$ factorial was used with 6 replicates per treatment. There were three phosphorus sources (calcium and sodium phosphate, micro granulated dicalcium phosphate or triple super phosphate) and two phytase levels (0 or $1000 \mathrm{FTU} / \mathrm{kg}$ diet). It is considered that $100 \%$ of the phosphorus of corn and soybean meal becomes available after phytase action; it was thus possible to reduce total phosphorus levels ( $\mathrm{Pt}$ ) from $0.50 \%$ to $0.30 \%$ after phytase was added.

Calcium, phosphorus, fluorine and sodium contents were analyzed in phosphorus sources, as well as the particle size (Table 1). Experimental diets based on corn and soybean meal were formulated in order to contain the same levels of protein (18\% CP), energy (2800 kcal $\mathrm{ME} / \mathrm{kg}$ ) and calcium (3.64\%), according to Rostagno et al. (2000) (Table 2).

After the experimental period, forty-eight birds were randomly chosen for sampling during a period of eight days. The first four days were the adaptation period, and excretion sampling was carried out in the next four days, according to a completely randomized design with four repetitions of two birds distributed in 24 parcels. The birds housed in metabolism cages were given water ad libitum and controlled amounts of diets during this experimental period. The experimental diets used during this assay were similar to the diets used during the performance trial (Table 1).

After the adaptation period, excretion samplings were performed using 1\% ferric oxide in the diet as marker of the onset and end of sampling period. Trays covered with plastic were placed under the experimental cages for collecting excretions twice a day. Immediately after sampling, excretions were frozen until the end of the period. Before analyses, 


\begin{tabular}{lccc}
\hline Table 1- Analysis from the phosphorus sources. & & \\
Traits & Calcium and sodium phosphate & Micro granulated dicalcium phosphate & Triple super phosphate \\
Calcium (\%) & 20.29 & 24.09 & 15.10 \\
Phosphorus (\%) & 18.36 & 18.08 & 20.31 \\
Fluorine (\%) & 0.12 & 0.11 & 1.94 \\
Sodium (\%) & 6.82 & - & - \\
Particle size (mm) & 0.04 & 0.15 & 0.04 \\
\hline
\end{tabular}

\begin{tabular}{|c|c|c|c|c|c|c|}
\hline \multirow{3}{*}{ Ingredient } & \multicolumn{6}{|c|}{ Diets } \\
\hline & \multicolumn{2}{|c|}{$\begin{array}{c}\text { Calcium and sodium } \\
\text { phosphate }\end{array}$} & \multicolumn{2}{|c|}{$\begin{array}{c}\text { Micro granulated } \\
\text { dicalcium phosphate }\end{array}$} & \multicolumn{2}{|c|}{$\begin{array}{l}\text { Triple super } \\
\text { phosphate }\end{array}$} \\
\hline & Without enzym & With enzyme & Without enzyme & With enzyme & Without enzyn & ith enzyme \\
\hline Corn & 58.52 & 58.89 & 58.41 & 58.89 & 58.14 & 58.87 \\
\hline Soybean meal & 28.30 & 28.30 & 28.30 & 28.30 & 28.36 & 28.30 \\
\hline Soybean oil & 2.50 & 2.50 & 2.50 & 2.50 & 2.50 & 2.50 \\
\hline Calcium and sodium phosphate & 1.41 & 0.13 & - & - & - & - \\
\hline Dicalcium phosphate & - & - & 1.44 & 0.14 & - & - \\
\hline Triple super phosphate & - & - & - & - & 1.23 & 0.12 \\
\hline Limestone & 8.46 & 9.13 & 8.30 & 9.10 & 8.72 & 9.14 \\
\hline Salt & 0.28 & 0.50 & 0.52 & 0.52 & 0.52 & 0.52 \\
\hline Vitamin mineral premix ${ }^{A}$ & 0.50 & 0.50 & 0.50 & 0.50 & 0.50 & 0.50 \\
\hline DL-Methionine & 0.03 & 0.03 & 0.03 & 0.03 & 0.03 & 0.03 \\
\hline Phytase enzyme & - & 0.02 & - & 0.02 & - & 0.02 \\
\hline Total & 100 & 100 & 100 & 100 & 100 & 100 \\
\hline \multicolumn{7}{|l|}{ Calculated composition } \\
\hline Metabolizable energy ( $\mathrm{kcal} / \mathrm{kg}$ ) & 2,800 & 2,800 & 2,800 & 2,800 & 2,800 & 2,800 \\
\hline Sodium (\%) & 0.23 & 0.23 & 0.23 & 0.23 & 0.23 & 0.23 \\
\hline Available phosphorus(\%) & 0.36 & 0.12 & 0.36 & 0.12 & 0.36 & 0.12 \\
\hline Calcium (\%) & 3.64 & 3.64 & 3.64 & 3.64 & 3.64 & 3.64 \\
\hline Crude protein (\%) & 18.0 & 18.0 & 18.0 & 18.0 & 18.0 & 18.0 \\
\hline Methionine (\%) & 0.39 & 0.39 & 0.39 & 0.39 & 0.39 & 0.39 \\
\hline Methionine + Cystine (\%) & 0.68 & 0.68 & 0.68 & 0.68 & 0.68 & 0.68 \\
\hline \multicolumn{7}{|l|}{ Analyzed composition } \\
\hline Crude protein (\%) & 18.0 & 17.7 & 18.2 & 17.9 & 18.0 & 17.9 \\
\hline Nitrogen (\%) & 2.88 & 2.84 & 2.91 & 2.87 & 2.88 & 2.87 \\
\hline Calcium (\%) & 3.70 & 3.37 & 3.66 & 3.22 & 3.57 & 3.32 \\
\hline Total phosphorus (\%) & 0.55 & 0.32 & 0.51 & 0.31 & 0.52 & 0.33 \\
\hline
\end{tabular}

A - * Supplied per kilogram of diet: Vitamin A - 8,000 Ul; Vitamin D3 - 2,200 Ul; Vitamin E - 50 mg; Vitamin K3 - 3 mg; Vitamin B1 - 1.5 mg; Vitamin B2 - 4 mg; Vitamin B6 - 0.12 mg, Vitamin B12 - 15 mcg; Folic acid - 0.6 mg; Pantothenic acid - 10 mg; Niacin - 30 mg; Biotin - 0.1 mg; Choline chloride - 300 mg; Iron - 50 mg; Copper - 10 mg; Zinc - 70 mg; Manganese - 100 mg; lodine - 1 mg; Selenium - 0.3 mg; ethoxyquin - 50 mg.

the samples were thawed, homogenized, weighed and pre-dried at $55^{\circ} \mathrm{C}$ for 72 hours in forced air oven. Dried samples were ground and phosphorus, calcium and nitrogen were determined. Diets and excretion samples were analyzed according to AOAC (1995).

Data were statistically analyzed using SAS software (SAS, 1996) and means were compared by the Tukey's test at $5 \%$ of significance level.

\section{RESULTS AND DISCUSSION}

\section{Performance and eggshell quality}

Performance and eggshell quality during the periods from 32 to 48 and from 48 to 64 weeks of age are shown in Tables 3 and 4, respectively.

At the beginning and peak of laying period (Table 3 ) there were no significant effects of phosphorus source on performance parameters and eggshell quality. In regard to phytase addition, birds fed diets with no enzyme and therefore with higher levels of total phosphorus laid heavier eggs $(p<0.05)$ in comparison to birds fed phytase-supplemented diets with low levels of available phosphorus. In this first trial, it was also seen that the treatment with phytase improved eggshell quality (specific gravity and shell percentage). Eggshell quality improved with the decrease in egg size.

Different effects were found during the post-peak period (Table 4). There were no significant effects of phytase addition on performance and eggshell quality. However, phosphorus sources affected some variables. Triple super phosphate caused lighter eggs $(p<0.05)$ compared to the other sources. Hens fed calcium and sodium phosphate laid eggs with higher shell 


\begin{tabular}{|c|c|c|c|c|c|c|c|}
\hline (g/bird/day) & $\begin{array}{c}\mathrm{FI} \\
(\%)\end{array}$ & $\begin{array}{l}\text { EP } \\
\text { (g) }\end{array}$ & $\begin{array}{c}E W \\
(k g / k g)\end{array}$ & $\begin{array}{l}\text { FC } \\
(\%)\end{array}$ & $\begin{array}{c}\text { SP } \\
\left(\mathrm{g} / \mathrm{cm}^{3}\right)\end{array}$ & $\begin{array}{l}\text { ESG } \\
(\mathrm{mm})\end{array}$ & $\begin{array}{c}\text { ST } \\
\text { Phosphate }\end{array}$ \\
\hline \multicolumn{8}{|l|}{ source $(P)$} \\
\hline Calcium and sodium phosphate & 107.58 & 95.36 & 62.64 & 1.793 & 9.60 & 1.0909 & 0.384 \\
\hline Micro granulated dicalcium phosphate & 105.24 & 95.00 & 61.81 & 1.793 & 9.57 & 1.0909 & 0.377 \\
\hline Triple super phosphate & 105.51 & 93.29 & 62.28 & 1.810 & 9.54 & 1.0904 & 0.377 \\
\hline \multicolumn{8}{|l|}{ Phytase (Ph) } \\
\hline $0 \mathrm{FTU} / \mathrm{kg}$ diet & 106.45 & 94.48 & 62.79 a & 1.796 & $9.48^{b}$ & $1.0904^{b}$ & 0.379 \\
\hline 1000 FTU/kg diet & 105.76 & 94.62 & $61.70^{b}$ & 1.801 & $9.66^{a}$ & $1.0911^{\mathrm{a}}$ & 0.379 \\
\hline Interaction $(\mathrm{P} \times \mathrm{Ph})$ & NS & NS & NS & NS & NS & NS & NS \\
\hline CV $(\%)$ & 2.84 & 2.73 & 2.48 & 4.24 & 1.87 & 0.09 & 2.57 \\
\hline
\end{tabular}

$a, b-$ Means with different superscripts within a column are significantly different $(p<0.05)$.NS $=$ non-significant $(p>0.05)$.

\begin{tabular}{|c|c|c|c|c|c|c|c|}
\hline (g/bird/day) & $\begin{array}{c}\text { FI } \\
(\%)\end{array}$ & $\begin{array}{l}\text { EP } \\
(g)\end{array}$ & $\begin{array}{c}E W \\
(\mathrm{~kg} / \mathrm{kg})\end{array}$ & $\begin{array}{l}\mathrm{FC} \\
(\%)\end{array}$ & $\begin{array}{c}\mathrm{SP} \\
\left(\mathrm{g} / \mathrm{cm}^{3}\right)\end{array}$ & $\begin{array}{l}\text { ESG } \\
(\mathrm{mm})\end{array}$ & $\begin{array}{c}\text { ST } \\
\text { Phosphate }\end{array}$ \\
\hline \multicolumn{8}{|l|}{ source $(P)$} \\
\hline Calcium and sodium phosphate & 105.66 & $89.31^{a}$ & 63.83 & 1.876 & $9.54^{\mathrm{a}}$ & 1.0862 & $0.386^{a}$ \\
\hline Micro granulated dicalcium phosphate & 104.73 & 89.22 a & 63.52 & 1.866 & $9.49 a b$ & 1.0890 & $0.378 \mathrm{ab}$ \\
\hline Triple super phosphate & 105.44 & $86.57^{b}$ & 63.57 & 1.946 & $9.29 \mathrm{~b}$ & 1.0886 & $0.375^{b}$ \\
\hline \multicolumn{8}{|l|}{ Phytase (Ph) } \\
\hline $0 \mathrm{FTU} / \mathrm{kg}$ diet & 105.12 & 88.54 & 64.13 & 1.874 & 9.38 & 1.0880 & 0.381 \\
\hline 1000 FTU/kg diet & 105.43 & 88.19 & 63.15 & 1.918 & 9.50 & 1.0878 & 0.378 \\
\hline Interaction ( $\mathrm{P} \times \mathrm{Ph})$ & NS & NS & NS & NS & NS & NS & NS \\
\hline CV $(\%)$ & 3.70 & 3.57 & 2.39 & 4.91 & 2.69 & 0.47 & 1.26 \\
\hline
\end{tabular}

$a, b$ - Means with different superscripts within a column are significantly different $(p<0.05)$.NS = non-significant $(p>0.05)$.

percentage and shell thickness than hens fed triple super phosphate. Hens fed micro granulated dicalcium phosphate had results similar to the other treatments.

The lower performance and the poorest quality of eggs from hens fed triple super phosphate might be related to the fluorine levels in this source, once fluorine in excess should be considered a toxic mineral with accumulative effect (Veloso, 1991).

Fluorine contents in diets with triple super phosphate and non-supplemented with phytase was $0.024 \%$, whereas levels were $0.002 \%$ when phytase was supplemented. Levels higher than $0.057 \%$ should be considered toxic to hens. In our study, toxic effects of fluorine were observed only at the second phase of the study, indicating a putative accumulative effect responsible for the reduction of egg production and eggshell quality.

In terms of phytase utilization, it was evident that the addition of this enzyme permitted to reduce the level of available phosphorus $(0.12 \%)$ whereas performance was similar to that observed in hens fed diets with higher levels of available phosphorus $(0.36 \%)$, except for mean egg weight during the laying peak phase, which was reduced.

The reduction in the available phosphorus requirements and consequently in the inorganic phosphorus added to the diets of laying hen is largely reported. Gordon \& Roland (1997) evaluated the performance and eggshell quality in laying hens fed corn-soybean diets with different levels of available phosphorus ( 0.1 to $0.5 \%$ ) and two levels of phytase (0 and $300 \mathrm{U} / \mathrm{kg}$ ). There was a reduction in performance and eggshell quality in hens fed diets with $0.1 \%$ of phosphorus. However, these undesirable effects were reversed when $300 \mathrm{U}$ of phytase was added per kilogram of diet. It was also reported that there were no benefits of phytase addition when phosphorus level ranged from 0.2 to $0.5 \%$. Um \& Paik (1999) reported that the addition of $500 \mathrm{U}$ phytase per kilogram in corn-soybean meal based diet allowed the reduction of available phosphorus and inorganic phosphorus for laying hens.

It was also possible to reduce the levels of inorganic phosphorus supplemented to laying hens when phytase was added to diets with high levels of rice bran. No matter which phytase source was used in rice bran diets for laying hens, enzyme addition allowed to remove the inorganic phosphorus source from the diets with no changes in performance or decrease in eggshell quality (Tangendjaja et al., 2002).

\section{Excretion Traits}

There were no significant $(p>0.05)$ effects of 
phosphorus sources on mineral intake and excretion (Table 5). On the other hand, the supplementation of phytase in diets with low levels of available phosphorus resulted in lower phosphorus, calcium and nitrogen intake and fewer excretions. A reduction in phosphorus intake was expected, once phosphorus levels in phytase-supplemented diets were reduced in $40 \%$. Calcium and nitrogen intakes were also reduced because the calcium and nitrogen contents of these diets were lower (Table 2). The addition of phytase to the diets resulted in great losses of phosphorus (47.1\%), calcium $(12.4 \%)$ and nitrogen $(17.4 \%)$ in the excretions.

Although these reductions were related to lower levels of available phosphorus, calcium and nitrogen in phytase-supplemented diets, it is necessary to point out that there were no adverse effects on performance or eggshell quality, except for mean egg weight during the laying peak. Therefore, phytase contributed to reduce the environmental impact of excretions, mainly the effects related to phosphorus levels. According to Barreto (1994), the increase of phosphorus contents in diets causes higher levels of phosphorus in the excreta.

The supplementation of phytase to the diet of laying hens causes the release of the phosphorus linked to phytate, and it becomes available to be metabolized by the bird. Thus, phosphorus levels in diets may be reduced and therefore decrease also in the excreta (Kornegay, 2001). Phytase addition to laying hen diets containing $0.25 \%$ of available phosphorus increased phosphorus retaining in 139\% and nitrogen and calcium were retained $25 \%$ and $32 \%$ more, respectively (Nahashon et al., 1994).

The effects of phytase also on nitrogen and calcium retaining and, consequently, on their excretion, evidenced that this enzyme has and effective role on releasing these minerals from phytate-protein-amino acid complex, enhancing mineral metabolization by birds.
An excellent report on phytase effects on phytatephosphorus and phytate-protein complexes was published by Keshavarz \& Austic (2004). In that trial, low phosphorus and low protein diets were supplemented with limiting amino acids and phytase and there were no effects on bird performance compared to the control diet, although nitrogen and phosphorus excretions were reduced in approximately $45 \%$ and $48 \%$, respectively.

\section{CONCLUSIONS}

Considering the evaluated phosphorus sources, triple super phosphate had undesirable long-term effects on commercial laying hen performance and eggshell quality. The addition of 1000 FTU phytase/kg diet permitted to reduce dietary phosphorus levels and decreased the losses of phosphorus, calcium and nitrogen in the excreta. However, diets with low phosphorus levels reduced mean egg weight during the laying peak period.

The supplementation of laying hen diets with phytase might be an alternative to reduce the environmental impact of bird manures, especially when it is to be added to the soil.

\section{REFERENCES}

Association of Official Analytical Chemists. Official methods of analysis of the Association of Official Analytical Chemists. Washington. 16th ed. 1995; 1:960.52/12.1.07.

Barreto SLT. Efeito de níveis de fósforo disponível durante o pico de postura para duas linhagens de poedeiras comerciais leves. [Dissertação]. Lavras (MG): Universidade Federal de Lavras; 1994.

Boling SD, Douglas MW, Johnson ML, Wang $X$, Parsons $C M$, Koelkebeck, KW, Zimmerman R. A. The effects of dietary available phosphorus levels and phytase on performance of young and older laying hens. Poultry Science 2000; 79:224-230.

\begin{tabular}{|c|c|c|c|c|c|c|}
\hline & \multicolumn{2}{|c|}{ Phosphorus (mg) } & \multicolumn{2}{|c|}{ Calcium $(g)$} & \multicolumn{2}{|c|}{ Nitrogen (g) } \\
\hline & Ingestion & Excretion & Ingestion & Excretion & Ingestion & Excretion \\
\hline \multicolumn{7}{|l|}{ Phosphate source (P) } \\
\hline Calcium and sodium phosphate & 388 & 289 & 3.14 & 1.13 & 2.53 & 1.48 \\
\hline Micro granulated dicalcium phosphate & 382 & 279 & 3.19 & 1.10 & 2.65 & 1.36 \\
\hline Triple super phosphate & 378 & 279 & 3.09 & 0.96 & 2.58 & 1.40 \\
\hline \multicolumn{7}{|l|}{ Phytase (Ph) } \\
\hline 0 FTU/kg diet & $496^{a}$ & $369^{\text {a }}$ & $3.42^{a}$ & 1.13 & $2.69^{a}$ & $1.55^{a}$ \\
\hline 1000 FTU/kg diet & $269^{b}$ & $195^{b}$ & $2.86^{b}$ & 0.99 & $2.48^{b}$ & $1.28^{b}$ \\
\hline Interaction $(P \times P h)$ & NS & NS & NS & NS & NS & NS \\
\hline CV (\%) & 6.49 & 12.12 & 6.54 & 18.02 & 6.02 & 9.68 \\
\hline
\end{tabular}

$a, b-$ Means with different superscripts within a column are significantly different $(p<0.05)$. NS = non-significant ( $>>0.05)$. 
Borrmann MS, Bertechini AG, Fialho ET, Oliveira BL. Efeitos da adição de fitase com diferentes níveis de fósforo disponível em rações de poedeiras de segundo ciclo. Ciência Agrotécnica 2001; 25:181-187.

Burnell TW, Cromwell GL, Stahly TS. Effect of particle size on biological availability of calcium and phosphorus in defluorinade phosphate for chickens. Poultry Science 1990; 69:110-117.

Ceylan N, Scheideler SE, Stillborn HL. High available phosphorus corn and phytase in layer diets. Poultry Science 2003; 82:789-795.

Cousins B. Enzimas na nutrição de aves. In: I Simpósio Internacional ACAV-Embrapa sobre Nutrição de aves 17 e 18 de novembro de 1999, Concórdia, SC.

Fireman AKBAT, Fireman FA. Fitase na alimentação de poedeiras. Ciência Rural 1998; 28:529-534.

Gordon RW, Roland DA. Performance of commercial laying hens fed various phosphorus levels, with and without supplemental phytase. Poultry Science1997; 76:1172-1177.

Jalal MA, Scheideler SE. Effect of supplementation of two different sources of phytase on egg production parameters in laying hens and nutrient digestibility. Poultry Science 2001; 80:1463-1471.

Keshavarz K, Austic RE. The use of low-protein, low-phosphorus, amino acid and phytase supplemented diets on laying hen performance and nitrogen and phosphorus excretion. Poultry Science 2004; 83:83-75.

Kornegay ET. Digestion of phosphorus and other nutrients: the role of phytases and factors influencing their activity. Enzymes in farm animal nutrition. CAB International, London, 406 p., 2001.

Nahashon SN, Nakaue HS, Mirosh LW. Phytase activity, phosphorus and calcium retention, and performance of single comb White
Leghorn layers fed diets containing two levels of available phosphorus and supplemented with direct-feed microbial. Poultry Science 1994; 73:1552-1562

Perdomo CC. Impacto da suinocultura sobre o meio ambiente. II suinotec. In: Conferência internacional sobre ciência e tecnologia de produção e industrialização de suínos. 1996, Campinas, São Paulo. Anais...p. 87-97, 1996.

Potter LM. Biological value of phosphorus from various sources for young turkeys. Poultry Science 1988; 67:96-102.

Rostagno HS, Silva DJ, Costa PMA. Composição de alimentos e exigências nutricionais (Tabelas Brasileiras). Ed. Imprensa Universitária. Viçosa, MG. 2000, 139p.

SAS Institute. SASÒ (Statistical Analysis System). User's Guide: Statistics. Cary, NC: SAS Institutte Inc., 1996.

Syers KJ, Harris RF, Armstrong DE. Phosphate chemistry in lake sediments. Journal of Environmental Quality 1973; 2:1-14.

Tangendjaja B, Chung TK, Broz J. Effects of different sources of microbial phytase on production performance of brown-egg layers fed diets containing a high level of rice bran. Journal Applied Poultry Research 2002; 11:212-216.

Um JS, Paik IK. Effects of microbial phytase supplementation on egg production, eggshell quality, and mineral retention of laying hens fed different levels of phosphorus. Poultry Science 1999; 78:75-79.

Veloso JAF. Perspectivas de uso dos fosfatos de rocha na alimentação animal. Cadernos Técnicos da Escola de Veterinária 1991; 6:55-84.

Yi ZY, Kornegay ET, Denbow DM. Supplemental microbial phytase improves zinc utilization in broilers. Poultry Science 1996; 75:540546. 